Соболєва T. O. ${ }^{[1 ; 0 R C I D ~ I D: ~ 0000-0002-7818-145 X], ~}$ к.е.н., доцент кафедри менеджменту,

Якубова К. В. [1; ORCID ID: 0000-0002-2058-0490], здобувач вищої освіти третього (освітньо-наукового) рівня

${ }^{1}$ Київський національний економічний університет імені Вадима Гетьмана, м. Київ

\title{
СТРАТЕГІЧНЕ УПРАВЛІННЯ ІНТЕЛЕКТУАЛЬНИМИ АКТИВАМИ ОРГАНІЗАЦІї
}

Поширення економіки знань на тлі глобалізації та розвитку нових технологій зумовлює особливу увагу в процесі управління організацією до інтелектуальних активів як основного джерела капіталізації бізнесу та створення конкурентних переваг на ринку. Створення та ефективне використання інтелектуальних активів можливе за умови здійснення в організації цілеспрямованого управління такими активами, в тому числі розробки стратегії розвитку цієї сфери бізнесу. Важливими аспектами при цьому виступають ідентифікація та аудит інтелектуальних активів, їх каталогізація, узгодження стратегії управління інтелектуальними активами 3 іншими стратегіями в організації, комерціалізація та охорона прав на інтелектуальну власність. Всі ці етапи вимагають концептуального системного підходу, планування i використання сучасної успішної практики на ринку.

Ключові слова: інтелектуальні активи; стратегічне управління; стратегія, аудит; інтелектуальна власність.

Постановка проблеми. В сучасних умовах основною цінністю стає розвиток освітнього, інтелектуального і творчого потенціалу людини, як основних джерел реалізації інтелектуальної діяльності. В даний час більша частка ВВП розвинених країн сформовано за рахунок технологій, які були створені за допомогою нових знань та ідей. Визнано, що наукові знання і спеціалізовані унікальні навички їх носіїв стають головним джерелом розвитку матеріального і нематеріального виробництва, забезпечення сталого економічного розвитку [1]. Особлива увага до питання управління інтелектуальними активами (IA) викликана зміщенням акцентів 3 матеріальних активів на процеси реалізації інновацій та спрямовуванням інвестицій в розвиток нематеріальних та інтелектуальних активів.

У науково-практичній літературі немає єдиного підходу до трактування категорій «інтелектуальні активи», «нематеріальні 
активи», «інтелектуальний капітал», що призводить до труднощів в управлінні і в отриманні оптимальних результатів комерціалізації інновацій. Поняття «активи» має багато визначень, наприклад, «сукупність майнових прав (матеріальних цінностей, грошових коштів і т.д.), що належать фізичній або юридичній особі» [2]. Критеріями визнання інтелектуальних активів, позначених в стандартах фінансової звітності, $€$ наступні: ІА повинні акумулювати в собі майбутню економічну вигоду; повинні контролюватися підприємством, вартість може бути достовірно оцінена [3].

Інтелектуальні активи включають в себе дві групи об'єктів об'єкти інтелектуального капіталу, відображені у звітах і мають форму нематеріальних активів; об'єкти, не включені в систему звітності. При цьому нематеріальні активи, які не відображаються в бухгалтерській звітності, називаються гудвілом (різниця між балансовою і ринковою вартістю активів), який здатний генерувати вартість активів і синергетичних ефектів [4].

Досить часто в нормативних документах інтелектуальні активи розуміють як складову нематеріальних активів разом з правами власності або іншими правами на ці активи. При цьому не враховуються такі інтелектуальні активи, як кваліфікація працівників при виконанні службових обов'язків; наявність унікальної стратегії розвитку компанії; кваліфікований менеджмент, здатний реалізовувати й трансформувати певні стратегії компанії. Також, у зв'язку з цим, можна вказати результати проведення маркетингових досліджень для успішного виведення товару на ринок; досвід взаємин з покупцями і постачальниками; унікальні ідеї, що сприяють удосконаленню процесу виробництва, скорочення витрат; створення рекламних кампаній для більш успішного просування продукції на ринку тощо.

Коли до інтелектуальних активів відносять тільки ті активи, які вдалося виявити, описати і віднести на баланс підприємства, тоді частина невиявлених і не віднесених на баланс компанії активів не зможуть піддаватися управлінському впливу, що не дозволить отримати додаткові вигоди від їх використання. Однак практика показує, що використання інтелектуальних активів не обов'язково пов'язане 3 їх відображенням в балансі. їх ідентифікація вже дозволяє виконувати ефективне управління ними в подальшому.

Постановка завдання. Створення, акумулювання та ефективне використання інтелектуальних активів можливе лише за умови наявності ефективної системи управління такими активами в організації. Оскільки інтелектуальні активи все більше сприяють розвитку бізнесу, кожна організація повинна мати стратегію 
управління інтелектуальними активами. Успішне управління портфелем інтелектуальних активів означає узгодження стратегії управління інтелектуальною власністю з цілями і завданнями всього бізнесу. Якщо стратегія управління інтелектуальними активами відсутня, існує високий ризик втрати інтелектуальних активів, а також і конкурентних переваг. Управління інтелектуальними активами вимагає комплексного підходу, який фокусує увагу на всіх активах підприємства 3 метою їх створення та отримання максимальної вигоди від їх використання.

Основні результати дослідження. Інтелектуальні активи здатні не тільки впливати на збільшення балансової вартості, а також забезпечують капіталізацію компанії 3 можливістю додаткового залучення інвестиційних ресурсів. Інтелектуальні активи в сучасній економіці є невід'ємною частиною потенціалу розвитку організації, а також її конкурентоспроможності на ринку [5] у довгостроковій перспективі. До інтелектуальних активів організації може бути віднесено багато об'єктів, серед яких особливе місце займають патенти та торгові марки. Це можуть бути національні патенти, або отримані в інших країнах; також твори, що охороняються авторським правом; товарні знаки; промислові зразки та інші форми зареєстрованої інтелектуальної власності. Інтелектуальні активи включають як зареєстровану, так і незареєстровану інтелектуальну власність: комерційні секрети, особливості бізнес-процесів, проектні специфікації, вихідні коди програмного забезпечення та інші неопубліковані ноу-хау. Таким чином, управління інтелектуальними активами - це набагато більше ніж просто процес патентування та ліцензування винаходів. У процесі управління повинні враховуватися всі інтелектуальні активи з урахуванням специфіки ресурсів та сфери діяльності. У більшості компаній патенти виступають лише частиною нематеріальних активів. Активно використовуються також службова інформація, ідеї та комерційна таємниця. Інформація, яку також слід враховувати при управлінні інтелектуальними активами, може містити формули речовин і склад продуктів, виробничі процеси, плани запуску нових продуктів, напрямки досліджень, методи тестування, бізнес-плани, стратегії, умови постачальників, аналіз конкуренції, списки клієнтів, маркетингові плани, прогнози продажів, бюджети, фінансові прогнози, аналіз цін і списки співробітників.

Управління інтелектуальними активами має передбачати послідовну реалізацію ключових етапів їх створення та реалізації (рисунок). Кожен етап пов'язаний з наступним і зумовлює його, що 
призводить до більшої ефективності здійснюваних дій. В результаті забезпечується синхронізація між збором науково-технічної інформації, іï захистом, аналізом активів і ліцензуванням інтелектуальної власності. В результаті компанія в ході управління інтелектуальними активами досягає ефективності в багатьох бізнеспроцесах. Важливим елементом управління $\epsilon$ зіставлення результатів аналізу внутрішніх і зовнішніх чинників для розробки i реалізації стратегії управління інтелектуальними активами. При цьому повинні враховуватися прийняті в компанії політика управління IA, а також стратегії управління діяльністю компанії на всіх рівнях.

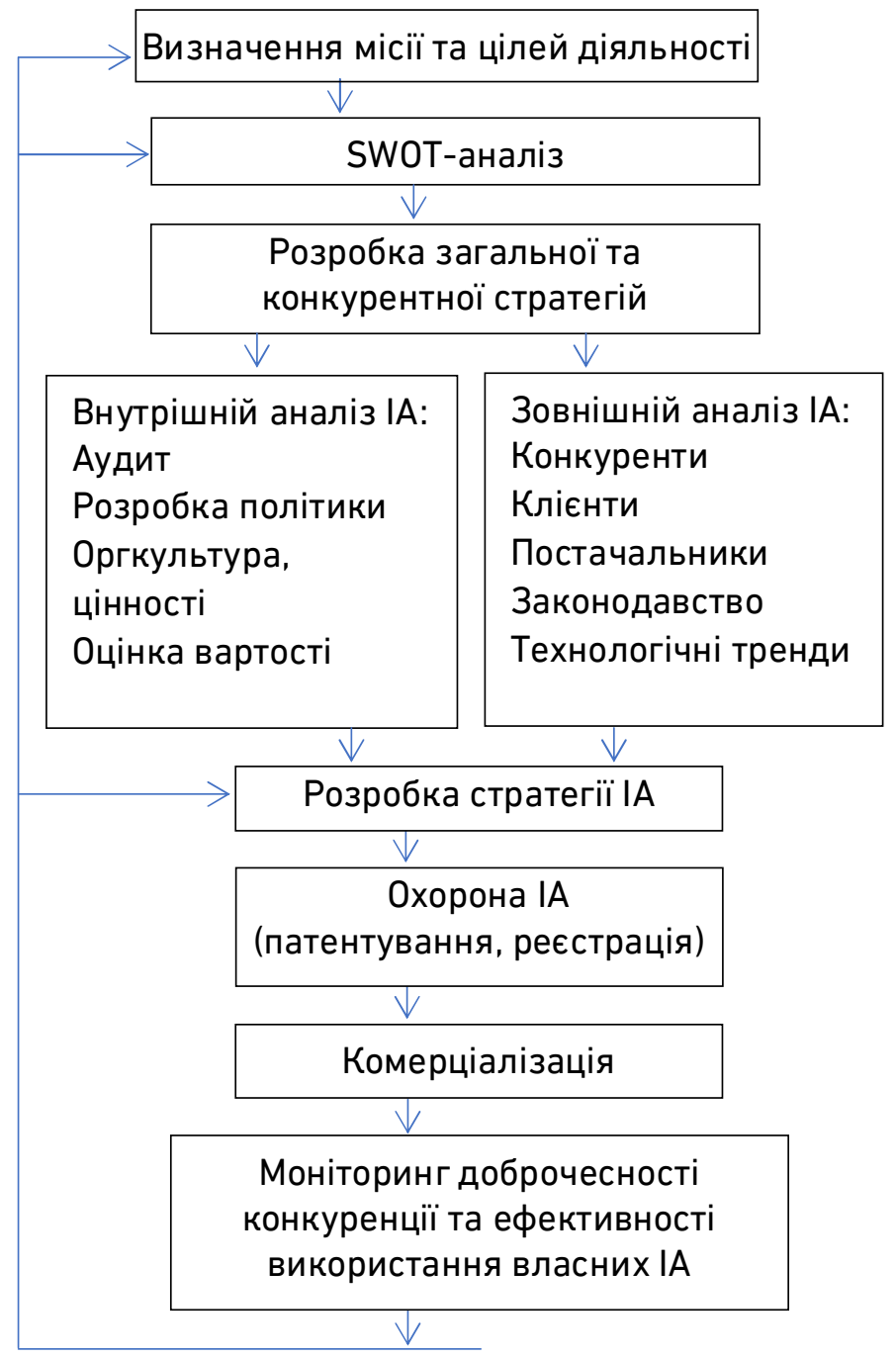

Рисунок. Етапи стратегічного управління інтелектуальними активами Джерело: власна розробка 
Ефективний підхід до управління інтелектуальними активами спрямований на вирішення наступних чотирьох завдань [6]:

1. Виявлення нематеріальних активів для систематизації інформації про потенційну цінність інтелектуальної власності, яку компанія може використовувати для збільшення доходу.

2. Захист нематеріальних активів, щоб гарантувати, що компанія може зберегти свої майнові права на ці активи.

3. Оптимізація вартості активів організації.

4. Створення нематеріальних активів, які 3 найбільшою ймовірністю збільшать прибуток.

Створення інтелектуальних активів - це цілеспрямований процес генерування інформації, яка призводить до створення інтелектуальної власності, яку можна комерціалізувати і отримати прибуток.

Важливим в даному контексті $€$ рівень знань персоналу [7] i створення організаційної культури [8]. Ефективне управління IA вимагає зусиль всієї організації. Створення повсюдної «культури інтелектуальної власності» $€$ найбільш ефективним способом реалізації успішної стратегії управління IA [9]. Чим більше доводиться до співробітників інформації про те, що робить керівництво, і що потрібно робити їм для максимального збільшення ефективності портфелю інтелектуальних активів, тим більш успішним буде реалізація стратегії.

Важливим етапом в будь-якій організації, яка управляє інтелектуальними активами, $€$ проведення моніторингу (аудиту) існуючих активів [10]. Це є особливо важливим для організацій, чий портфель IA збільшився за рахунок, наприклад, недавнього зростання, придбань, внутрішніх досліджень і розробок або продажу активів. В процесі аудиту потрібно звернути увагу на права власності на інтелектуальні активи, а саме: які об'єкти є власністю компанії, а які отримані або передані за ліцензією. Потрібно проводити огляд незапатентованих винаходів, патентних заявок, виданих патентів. Звернути увагу на права власності і умови договорів зі створення програмного забезпечення, розробленого організацією або для неї. Дуже важливим є виявлення комерційних секретів, зосередження уваги на закритій інформації, яка підвищує цінність організації, включаючи інтелектуальні активи, такі як списки клієнтів, процеси, прототипи на ранній стадії і стратегічні плани. Потрібно звернути увагу на зареєстровані і незареєстровані торгові марки, які використовуються організацією в різних юрисдикціях.

Результати аудиту можуть бути візуалізовані у вигляді простого списку активів або можуть деталізуватися у більш докладній таблиці 
або електронному каталозі. Він може, наприклад, включати більш складні системи відстеження, які супроводжуються юристами 3 інтелектуальної власності, які дозволяють відстежувати ліцензійні платежі і дотримання термінів продовження дії прав на зареєстровану інтелектуальну власність.

Організація також повинна інформувати свій персонал про стратегічну важливість інтелектуальної власності. Цей процес передбачає підвищення обізнаності про різні типи інтелектуальної власності, а також політики організації щодо цих активів. У цьому процесі має брати участь керівництво організації, демонструючи важливість створення і захисту інтелектуальних активів компанії. Стратегія управління IA повинна бути інтегрована в загальну бізнесстратегію, а також включати внутрішні елементи політики, такі як політика конфіденційності і розкриття інформації про винаходи. Політика конфіденційності компанії підкреслює важливість збереження секретності до тих пір, поки не буде подана патентна заявка або вдосконалений продукт не буде виставлений на продаж. Юристи 3 інтелектуальної власності можуть також відігравати важливу роль в навчанні і бути джерелом розробки внутрішньої політики, аналізу угод та складання положень договорів, що регулюють правовідносини з питань інтелектуальної власності.

Крім ідентифікації, обліку, аудиту, каталогізації та захисту, важливою метою управління інтелектуальними активами $€$ їх ефективне використання. Використання інтелектуальних активів може приймати різні форми. Компанія може використовувати свої активи, переслідуючи традиційну мету - домогтися винятковості на ринку і не допустити конкурентів у свій сегмент. Монетизація інтелектуальної власності за допомогою ліцензійних угод - звичайна практика, яка використовується як комерційними, так i некомерційними організаціями. Доступ до технологій через спільні підприємства та стратегічні альянси може бути ще однією стратегією використання. Іноді використання інтелектуальних активів може бути просто перевагою для зв'язків з громадськістю і не мати нічого спільного з потоком грошових коштів. Наприклад, IBM довгий час ставила перед собою мету бути лідером за кількістю щорічно видаються патентів, щоб підвищити свою репутацію інноваційної компанії-винахідника [9]. Методи використання та монетизації портфелю інтелектуальної власності постійно розширюються. Деякі з варіантів включають отримання позики під забезпечення інтелектуальної власності, патентні аукціони, судові суперечки, прямий продаж або передачу прав на інтелектуальний актив. 
Висновки. Забезпечення дотримання прав на інтелектуальні активи $є$ одним 3 найбільш витратних аспектів управління портфелем інтелектуальної власності, який включає в себе як дотримання прав за допомогою обов'язкових платежів, так і відстоювання прав в судовому порядку проти дій порушників. Як і в інших сферах бізнесу, щоб отримувати більше з меншими витратами, потрібне планування, співпраця і відповідна стратегія. У міру того, як ринки стають глобальними, витрати, необхідні для ефективного контролю і забезпечення дотримання прав на торговельні марки та патенти, стають непомірно високими для деяких компаній. Для більшості компаній судовий процес $€$ кращою стратегією, однак судові розгляди стають все більш дорогими.

Таким чином, запорукою успішного управління нематеріальними активами в організації $\epsilon$ узгодження стратегії інтелектуальної власності 3 їі бізнес-стратегією. Важливими аспектами при цьому виступають ідентифікація (аудит) IA, їх каталогізація, узгодження стратегії IA з усім стратегічним набором в організації, ефективне використання IA і забезпечення дотримання прав на неї. Всі ці етапи вимагають концептуального системного підходу, планування і використання сучасної успішної практики на ринку.

1. Карпенко А. В. Державна стратегія ефективного використання економічних ресурсів в умовах світової глобалізації. Вісник Національного університету водного господарства та природокористування : зб. наук. праць. Економічні науки. 2014. Вип. 3(67). С. 126-135. 2. Борисов А.Б. Большой экономический словарь. М. : Книжный мир, 2006. 860 с. 3. Ибрагимов Е. Е. Моделирование влияния интеллектуальных активов на эффективность корпоративного управления с ориентацией на знания. Формирование рыночных отношений в Украине. 2012. № 5/1 (132). С. 119-124. 4. Ляшенко Н. Є. Проблеми оцінки інтелектуальних активів в управлінні. Управління проектами та розвиток виробництва. 2009. № 3. С. 58-67. URL: http://nbuv.gov.ua/UJRN/Uprv_2009_3_9. (дата звернення: 10.11.2020). 5. Стратегічне управління конкурентоспроможністю: системний метод та екзистенціальна експозиція: монографія / Мошак С. М., Мікловда В.П., Шандор Ф. Ф., Кубіній Н. Ю., Кубіній В. В. Мукачево: Карпатська вежа. 2017. 240 с. 6. Fine N. R. Intellectual Asset Management: From Information to Intellectual Property to Profit. Pro-Tec Dat. 2003. URL: http://www.pro-tecdata.com/pdf/IAMInfolPProfit.pdf/_(дата звернення: 10.11.2020). 7. Gagnidze I. The role of international educational and science programs for sustainable development (systemic approach). Kybernetes. Vol. 47. No. 2. Pp. 409-424. 8. Paresashvili Nino. Corporate Culture In Terms Of Labor Diversity. Smart and Efficient Economy: Preparation for the Future Innovative Economy : International Conference. Brno, Czech Republic, 2016. Pp. 321327. 9. Krelitz Susan Prohofsky and Sellke Alex (2014). Intellectual Asset Management at the Speed of Business. Cybaris ${ }^{\circledR}$. Vol. 5. Iss. 1. Article 2. URL: http://open.mitchellhamline.edu/cybaris/vol5/iss1/2 (accessed: 10.11.2020). 10. Stobbe R. Intellectual asset management best practices. Part 1. Field Law. 2014. URL: $\quad$ https://www.lexology.com/library/detail.aspx?g=172f939b-eee1-43ec-9413- 


\section{REFERENCES:}

1. Karpenko A. V. Derzhavna stratehiia efektyvnoho vykorystannia ekonomichnykh resursiv $v$ umovakh svitovoi hlobalizatsii. Visnyk Natsionalnoho universytetu vodnoho hospodarstva ta pryrodokorystuvannia : zb. nauk. prats. Ekonomichni nauky. 2014. Vyp. 3(67). S. 126-135. 2. Borisov A. B. Bolshoy ekonomicheskiy slovar. M. : Knijnyiy mir, 2006. 860 s. 3. Ibragimov E. E. Modelirovanie vliyaniya intellektualnyih aktivov na effektivnost korporativnogo upravleniya $\mathrm{s}$ orientatsiey na znaniya. Formirovanie ryinochnyih otnosheniy v Ukraine. 2012. № 5/1 (132). S. 119-124. 4. Liashenko N. Ye. Problemy otsinky intelektualnykh aktyviv $\mathrm{v}$ upravlinni. Upravlinnia proektamy ta rozvytok vyrobnytstva. $2009 . \quad$ № $3 . \quad$ S. 58-67. URL: http://nbuv.gov.ua/UJRN/Uprv_2009_3_9. (data zvernennia: 10.11.2020). 5. Stratehichne upravlinnia konkurentospromozhnistiu: systemnyi metod ta ekzystentsialna ekspozytsiia : monohrafiia / Moshak S. M., Miklovda V. P., Shandor F. F., Kubinii N. Yu., Kubinii V. V. Mukachevo : Karpatska vezha. 2017. 240 s. 6. Fine N. R. Intellectual Asset Management: From Information to Intellectual Property to Profit. Pro-Tec Dat. 2003. URL: http://www.pro-tecdata.com/pdf/IAM-InfolPProfit.pdf/ (data zvernennia: 10.11.2020). 7. Gagnidze I. The role of international educational and science programs for sustainable development (systemic approach). Kybernetes. Vol. 47. No. 2. Pp. 409-424. 8. Paresashvili Nino. Corporate Culture In Terms Of Labor Diversity. Smart and Efficient Economy: Preparation for the Future Innovative Economy: International Conference. Brno, Czech Republic, 2016. Pp. 321-327. 9. Krelitz Susan Prohofsky and Sellke Alex (2014). Intellectual Asset Management at the Speed of Business. $\quad$ Cybaris $^{\circledR}$. Vol. 5 . Iss. 1. Article 2. URL: http://open.mitchellhamline.edu/cybaris/vol5/iss1/2 (accessed: 10.11.2020). 10. Stobbe R. Intellectual asset management best practices. Part 1. Field Law. 2014. URL: https://www.lexology.com/library/detail.aspx?g=172f939b-eee1-43ec-9413ff45d0462cc4 (accessed: 10.11.2020).

Sobolieva T. O. [1; ORCID ID: 0000-0002-7818-145X],
Candidate of Economics (Ph.D.), Associate Professor, Deputy Head
of Management Department
Yakubova K. V. ${ }^{[1 ; \text { ORCID ID: 0000-0002-2058-0490], }}$,
Post-graduate Student, Management Department

${ }^{1}$ Kyiv National Economic University named after Vadym Hetman, Kyiv

\section{STRATEGIC MANAGEMENT OF THE ORGANIZATION`S INTELLECTUAL ASSETS}

In modern conditions, the main value becomes the development of educational, intellectual and creative potential of human as the main sources of intellectual activity. Particular attention to the issue of intellectual asset management is caused by the shift of emphasis from tangible material assets to the implementation of innovations and the direction of investment in the development of intangible and intellectual assets. Intellectual assets 
can not only increase the book value, but also provide capitalization of the company with possible entanglement of additional investment resources. Creation and use of intellectual assets, their capitalization and commercialization led to the emergence of new business processes in organizations. Creation, accumulation and effective use of intellectual assets are possible only if there is an effective management system for such assets in the organization. As intellectual assets increasingly contribute to business development, every organization must have an intellectual asset management strategy. An important step in any organization that manages intellectual assets is to monitor (audit) existing assets.

The organization should also inform its staff about the strategic importance of intellectual property within the organization. It is a process of raising awareness of different types of intellectual property, as well as the organization's policy on these assets. The management of the organization should take part in this process, demonstrating the importance of creating and protecting the company's intellectual assets. The intellectual asset management strategy should be integrated into the overall business strategy, as well as include internal policy elements such as privacy policy. Providing abidance of rights on intellectual assets is one of the most costly aspects of intellectual property portfolio management, which includes both mandatory payments and litigation against infringers' actions. The key to successful management of intangible assets in the organization is to align the intellectual property strategy with its business strategy. Important aspects are the identification and audit of intellectual assets, their cataloging, and coordination of intellectual asset management strategy with other strategies in the organization, commercialization and protection of intellectual property rights. All these stages require a conceptual systems approach, planning and using of modern successful practices in the market.

Keywords: intellectual assets; strategic management; strategy; audit; intellectual property.

Соболева T. А. ${ }^{[1 ; 0 R C I D ~ I D: ~ 0000-0002-7818-145 X], ~}$ к.э.н., доцент кафедры менеджмента

Якубова К. В. [1; ORCID ID: 0000-0002-2058-0490] соискатель высшего образование третьего (образовательно-научного) уровня

${ }^{1}$ Киевский национальный экономический университет имени Вадима Гетьмана, г. Киев

СТРАТЕГИЧЕСКОЕ УПРАВЛЕНИЕ ИНТЕЛЛЕКТУАЛЬНЫМИ АКТИВАМИ ОРГАНИЗАЦИИ

Распространение экономики знаний на фоне глобализации и развития новых технологий предопределяет особое внимание в процессе управления организацией к интеллектуальным активам как основному 
источнику капитализации бизнеса и создания конкурентных преимуществ на рынке. Создание и эффективное использование интеллектуальных активов возможно при условии осуществления в организации целенаправленного управления такими активами, в том числе разработки стратегии развития этой сферы бизнеса. Важными аспектами при этом выступают идентификация и аудит интеллектуальных активов, их каталогизация, согласование стратегии управления интеллектуальными активами с другими стратегиями в организации, коммерциализация и охрана прав на интеллектуальную собственность. Все эти этапы требуют концептуального системного подхода, планирования и использования современной успешной практики на рынке.

Ключевые слова: интеллектуальные активы; стратегическое управление; стратегия; аудит; интеллектуальная собственность.

Стаття надійшла до редакції 01.12.2020 p. 